\title{
Role of Plasma Connective Tissue Growth Factor Levels in Assessment of Pulmonary Arterial Hypertension in Children with Congenital Heart Disease
}

\author{
WALEED M. EL GENDY, M.D.; IMAN M. EL SAYED, M.D. and MUHAMMAD M. AMIN, M.Sc. \\ The Department of Pediatrics, Faculty of Medicine, Ain Shams University
}

\begin{abstract}
Background: To investigate plasma Connective Tissue Growth Factor (CTGF) levels in Pulmonary Arterial Hypertension (PAH) associated with Congenital Heart Disease (PAH-CHD) in children and the relationships of CTGF with hemodynamic parameters. Plasma CTGF levels were calculated in 30 children with PAH-CHD and 30 health volunteers, using the subtraction method.
\end{abstract}

Aim of Study: To assess plasma Connective Tissue Growth Factor (CTGF) levels in children with CHD and study its role in assessment of PAH that can be promising diagnostic and prognostic biomarkers for PAH in children with CHD.

Patients and Methods: Our study was conducted in Pediatric Cardiology Clinic and Cardiology Catheter Laboratory of Ain Shams University Pediatric Hospital, in the period from Jan. 2019 to May 2020, including 30 patient and 30 healthy controls of matched age and sex.

Results: The patients with PAH, 17 were acyanotic and 13 were cyanotic. The health control group and patient groups did not differ significantly in terms of age, gender and BSA $(p>0.05)$. Height, weight and BMI were significantly lower in PAH-CHD group compared with the HCG $(p<0.05)$, while no difference was found between PAH-CHD group ( $p>0.05)$. In addition, CTGF levels were higher in PAH-CHD group than health control group. Depicts that, PAH-CHD group had higher PASP, PADP, RVSP, mPAP, Qp, Rp and Rp/Rs ( $p<0.01)$

Conclusion: Plasma CTGF levels could be a promising diagnostic biomarker for PAH-CHD in children.

Key Words: Pulmonary arterial hypertension - Congenital heart disease.

\section{Introduction}

PULMONARY Arterial Hypertension (PAH) is a severe progressive disease with high mortality and morbidity leading to elevated pulmonary vascular resistance, right heart failure and death [1] . Clini-

Correspondence to: Dr. Muhammad M. Amin, E-Mail: dr mam.2010@yahoo.com cally, the disease is defined as a mean pulmonary artery pressure of $>25 \mathrm{mmHg}$ at rest [2].

The incidence of PAH secondary to congenital heart disease is estimated as 1.6-12.5 case/million/ year. The increased pulmonary blood flow in Congenital Heart Disease (CHD) with left-to-right shunts induces endothelial cell injury and apoptosis and increases pulmonary arterial pressure with neo-intimal development and pulmonary vascular remodeling [3]. Specific PAH-target drugs have improved the quality of life and survival by preventing pulmonary vascular remodeling [4]

PAH carried a poor prognosis in children with CHD. In the past years, some blood biomarkers in PAH such as B-type Natriuretic Peptide (BNP), N-Terminal pro-B-type Natriuretic Peptide (NTproBNP), endothelin-1, growth differentiation factor-15 and miRNAs have been used to diagnosis and prognosis, but none of them was validated to be an ideal biomarker [5].

Connective Tissue Growth Factor (CTGF), also known as CCN2, is a $38-\mathrm{kDa}$, cysteine-rich secreted peptide and belongs to the member of the $\mathrm{CCN}$ (acronym of Cyr61/CEF-10, CTGF/Fisp-12 and Nov) family of growth factors that was originally isolated from umbilical vein endothelial cells [6] CTGF is involved in normal physical condition, but also participates in pathological processes such as angiogenesis and wound healing, as well as extracellular matrix production, adhesion, proliferation and apoptosis [7]

More importantly, there are several observations that CTGF is intimately correlated with pulmonary vascular remodeling [8]. Many studies performed by Lee and Wang et al., at rats, found CTGF con- 
tributed to the proliferation of pulmonary artery smooth muscle cells these results suggest that CTGF should play an important role in the development of pulmonary vascular remodeling [9]

Plasma CTGF levels are shown to be useful in diagnosing heart failure [10], idiopathic pulmonary fibrosis Kono et al. [11], and correlate with the severity of fibrotic diseases [12]. We therefore hypothesize that secreted CTGF levels could be a clinical biomarker in children with PAH associated with CHD (PAH-CHD).

Right Heart Catheterization (RHC) is the gold standard method for diagnosis of $\mathrm{PAH}$ and an important tool for testing the eligibility of patients with CHD to undergo operations for correction of heart defects. However, it is an invasive test and not always practical for repeated ongoing evaluation. So, accurate noninvasive assessment of PAH is desirable both for diagnostic purposes and to assess response to therapy. Doppler echocardiography (D-ECHO) has become the most important and routinely applied noninvasive imaging technique for the diagnosis and follow-up of patients with CHD and is recommended as the initial noninvasive modality in the screening and evaluation of PAH [13]

\section{Aim of the work:}

The aim of this study is to assess plasma Connective Tissue Growth Factor (CTGF) levels in children with CHD and study its role in assessment of PAH that can be promising diagnostic and prognostic biomarkers for PAH in children with CHD. Also, to assess the diagnostic accuracy of Doppler $\mathrm{ECHO}$ as noninvasive technique in detecting $\mathrm{PAH}$ in patients with CHD and its value in detecting the ventricular remodeling and diastolic dysfunction induced by PAH to some extent.

\section{Patients and Methods}

Study population: Our study was conducted in Pediatric Cardiology Clinic and Cardiology Catheter Laboratory of Ain Shams University Pediatric Hospital, in the period from Jan. 2019 to May 2020 , including 30 patient and 30 healthy controls of matched age and sex.

The children were divided into two groups: Group A (study group): It is composed of 30 children. Detailed history and physical examination including age, gender, weight, height, Body Surface Area (BSA), Body Mass Index (BMI), electrocardiography and heart catheterization findings were recorded. Group B (control group): It is composed of 30 children excluded from any chronic diseases.

\section{Inclusion criteria:}

Age $<12$ years. Patients with PAH associated with CHD. Echocardiographic evidence of moderate to severe PHA. All control cases will be healthy with no clinical manifestation or history of chronic diseases.

\section{Exclusion criteria:}

Idiopathic PAH (IPAH). Patients with any chronic disease as connective tissue disease, liver disease, kidney disease, etc.

\section{Study tools and procedures:}

Complete history taking include age, sex, dietetic history, developmental history and history of any chronic diseases. General examination including, weight, height, Body Surface Area (BSA), Body Mass Index (BMI). Cardiac examination and modified Ross classification of heart failure. Sample collection from peripheral venous blood for assess plasma CTGF levels by using sandwich ELIZA. Ecocardiography: Echocardiographic examination will be performed for all cases in supineposition using General Electric (Vivid-E9) system with probe $5 \mathrm{~S}$ or $6 \mathrm{~S} \mathrm{MHz}$ (multifrequency transducer) according to age of patient. The examination will be done by a pediatric cardiologist who is expert in echocardiography. Two dimensional transthoracic echocardiography to detect the underlying congenital cardiac disease and the increased right-sided chamber size and wall thickness (RV dilatation and hypertrophy).c. Systolic, diastolic and mean pulmonary artery pressures will be evaluated by Doppler recordings of the maximal velocity of tricuspid regurgitation and early and late diastolic pulmonary regurge jet flow.

\section{Cardiac catheterization for assessment of:}

Mean pulmonary arterial pressure (mPAP). Mean right atrial pressure (mRAP) and left atrial pressure. Pulmonary Capillary Wedge Pressure (mPCWP). Qp can be estimated using Fick's principle by the following equation:

$$
\begin{gathered}
\mathrm{Qp}=\mathrm{VO}_{2} /\left(\text { pulmonary venous } \mathrm{O}_{2} \text { content }-\right. \\
\text { Pulmonary arterial } \left.\mathrm{O}_{2} \text { content }\right) .
\end{gathered}
$$

\section{Assay for plasma CTGF:}

After overnight fasting, blood samples for CTGF and BNP measurements were collected at 08$09 \mathrm{am}$, immediately transferred to chilled polypropylene tubes containing EDTA-2Na and centrifuged at $4^{\circ} \mathrm{C}$ and $2080 \mathrm{~g}$ for $15 \mathrm{~min}$. The plasma samples were stored at $-80^{\circ} \mathrm{C}$ and then thawed by incubating at $25^{\circ} \mathrm{C}$ for $5 \mathrm{~min}$ in a water preceding the CTGF assay. BNP was measured using the chemiluminescent microparticle immunoassay on the ARCHI- 
TECT 2000i System (Abbott; Abbott Park, IL, USA). Anti-CTGF antibodies were prepared, and each sandwich Enzyme-Linked Immunosorbent Assay (ELISA) was executed as described previously. The full-length CTGF levels were detected by a sandwich ELISA using two monoclonal antibodies against modules 1 and 4 . Total CTGF levels were determined by a sandwich ELISA using two monoclonal antibodies against modules 1 and 2 . N-terminal CTGF levels were calculated using a subtraction method, as follows: (N-terminal CTGF level $)=($ Total CTGF level) $($ full-length CTGF level). All analyses were performed in duplicate, and the mean value is reported for each.

\section{Statistical analysis:}

The values will used to describe mean \pm standard deviation. Comparison between groups will made using the Mann-Whitney U-test, Chi-square or rank sum test. Differences in CTGF levels in New York Heart Association (NYHA) classes willanalyzed by nonparametric Jonckheere-Terpstra. Receiver Operating Curve (ROC) analyses were assessed for diagnosis of PAH-CHD with MedCalc statistical software version 11.5.0.The differences between Area Under Curve (AUC) were evaluated by Hanley and McNeil methods (hanley, 1983). $p<0.05$ will be considered statistically significant.

\section{Results}

Table (1): Baseline clinical and laboratory characteristics of subjects.

\begin{tabular}{llcc}
\hline Variable & $\begin{array}{c}\text { HCG } \\
(\mathrm{n}=30)\end{array}$ & $\begin{array}{c}\text { PAH-CHD } \\
\text { group } \\
(\mathrm{n}=30)\end{array}$ & $\begin{array}{c}p \text {-value } \\
\text { (HCG vs. } \\
\text { PAH-CHD) }\end{array}$ \\
\hline Age (months) & $54.3 \pm 27.6$ & $53.7 \pm 38.8$ & 0.86 \\
Gender (F/M) & $15(10)$ & $16(14)$ & 0.62 \\
H (cm) & $99.3 \pm 24.5$ & $88.9 \pm 21.8$ & 0.021 \\
Weight $(\mathrm{Kg})$ & $17.6 \pm 8.2$ & $15.2 \pm 7.8$ & 0.009 \\
BSA $\left(\mathrm{m}^{2}\right)$ & $0.65 \pm 0.1$ & $0.61 \pm 0.2$ & 0.37 \\
BMI $\left(\mathrm{kg} / \mathrm{m}^{2}\right)$ & $16.7 \pm 5.7$ & $15.2 \pm 7.6$ & 0.01 \\
BNP $\left(\mathrm{pg} / \mathrm{ml}^{2}\right)$ & $52 \pm 20.7$ & $280.9 \pm 135.8$ & 0.000 \\
\hline Values are represented as mean \pm SD; & \\
$p<0.05$ was regarded as statistically significant. &
\end{tabular}

Table (2): Comparison of cardiac catheterization parameters among the studied groups.

\begin{tabular}{|c|c|c|}
\hline Variables & PAH-CHD $(n=30)$ & $p$-value \\
\hline PASP (mmHg) & $62.4 \pm 19.1$ & 0.000 \\
\hline PADP (mmHg) & $39.7 \pm 7.5$ & 0.000 \\
\hline $\mathrm{RVSP}(\mathrm{mmHg})$ & $50 \pm 13.7$ & 0.000 \\
\hline RVDP (mmHg) & $13.4 \pm 5.8$ & 0.07 \\
\hline mPAP $(\mathrm{mmHg})$ & $57.2 \pm 10.3$ & 0.000 \\
\hline $\mathrm{Qp}\left[\mathrm{L} /\left(\min \mathrm{m}^{2}\right)\right]$ & $19.1 \pm 2.1$ & 0.000 \\
\hline Qs $\left[\mathrm{L} /\left(\min \mathrm{m}^{2}\right)\right]$ & $4.6 \pm 1.6$ & 0.09 \\
\hline $\mathrm{Qp} / \mathrm{Qs}$ & $4.3 \pm 1.7$ & 0.08 \\
\hline $\mathrm{Rp}\left(\mathrm{U} X \mathrm{~m}^{2}\right)$ & $9.3 \pm 5.4$ & 0.000 \\
\hline $\mathrm{Rs}\left(\mathrm{UX} \mathrm{m}{ }^{2}\right)$ & $19.2 \pm 7.5$ & 0.15 \\
\hline $\mathrm{Rp} / \mathrm{Rs}$ & $0.49 \pm 0.35$ & 0.001 \\
\hline Oxygen saturation (\%) & $88.9 \pm 12.7$ & 0.13 \\
\hline
\end{tabular}

Table (3): Correlations of CTGF with various parameters in PAH-CHD patients.

\begin{tabular}{|c|c|c|}
\hline Parameters & Correlation coefficient & $p$-value \\
\hline Age (months) & -0.314 & 0.126 \\
\hline $\mathrm{H}(\mathrm{cm})$ & -0.216 & 0.300 \\
\hline Weight (Kg) & -0.22 & 0.291 \\
\hline $\operatorname{BSA}\left(\mathrm{m}^{2}\right)$ & -0.233 & 0.262 \\
\hline BMI $\left(\mathrm{kg} / \mathrm{m}^{2}\right)$ & -0.189 & 0.365 \\
\hline PASP (mmHg) & 0.386 & 0.057 \\
\hline PADP $(\mathrm{mmHg})$ & 0.056 & 0.790 \\
\hline RVSP (mmHg) & 0.265 & 0.201 \\
\hline $\mathrm{RVDP}(\mathrm{mmHg})$ & -0.132 & 0.529 \\
\hline $\mathrm{mPAP}(\mathrm{mmHg})$ & 0.370 & 0.069 \\
\hline $\mathrm{Qp}\left[\mathrm{L} /\left(\mathrm{min} \cdot \mathrm{m}_{2}^{2}\right)\right]$ & 0.385 & 0.094 \\
\hline Qs $\left[\mathrm{L} /\left(\mathrm{min} \cdot \mathrm{m}^{2}\right)\right]$ & 0.152 & 0.467 \\
\hline Qp/Qs & -0.27 & 0.898 \\
\hline $\mathrm{Rp}\left(\mathrm{U} / \mathrm{m}^{2}\right)$ & 0.035 & 0.868 \\
\hline $\operatorname{Rs}\left(\mathrm{U} / \mathrm{m}^{2}\right)$ & 0.067 & 0.751 \\
\hline $\mathrm{Rp} / \mathrm{Rs}$ & -0.165 & 0.432 \\
\hline Oxygen saturation (\%) & -0.436 & 0.016 \\
\hline $\mathrm{BNP}$ & 0.475 & 0.008 \\
\hline \multicolumn{3}{|c|}{ PASP : Pulmonary Artery Systolic Pressure. } \\
\hline \multicolumn{3}{|c|}{ PADP : Pulmonary Artery Diastolic Pressure. } \\
\hline \multicolumn{3}{|c|}{ RVSP : Right Ventricular Systolic Pressure. } \\
\hline \multicolumn{3}{|c|}{$\begin{array}{l}\text { RVDP : Right Ventricular Diastolic Pressure. } \\
\text { mPAP : Mean Pulmonary Artery Pressure. }\end{array}$} \\
\hline \multirow{2}{*}{\multicolumn{3}{|c|}{$\begin{array}{l}\text { mPAP : Mean Pulmonary Artery Pressure. } \\
\text { Qp : Pulmonary artery flow. }\end{array}$}} \\
\hline & & \\
\hline \multicolumn{3}{|c|}{ Qs $\quad$ : Systemic artery flow. } \\
\hline \multicolumn{3}{|c|}{ Qp/Qs : Pulmonary-to-systemic flow $\mathrm{r}$} \\
\hline $\mathrm{Rp} \quad$ : Pulmonary arteric & & \\
\hline $\begin{array}{l}\text { Rs } \\
\text { Rs Systemic arterial resistance. }\end{array}$ & sistance. & \\
\hline \multicolumn{3}{|c|}{$\mathrm{Rp} / \mathrm{Rs}$ : Pulmonary-to-systemic resis } \\
\hline
\end{tabular}

Table (4): Values of CTGF in PAH-CHD designated on the basis of ROC curves.

\begin{tabular}{lccccccrr}
\hline Test & AUC & Sensitivity (\%) & Specificity (\%) & PPV (\%) & NPV (\%) & + LR & - LR & $p$-value \\
\hline CTGF & 0.841 & 67 & 93 & 91 & 74 & 10.0 & 0.36 & $<0.0001$ \\
& $(0.724-0.923)$ & $(47-83)$ & $(78-99)$ & $(71-99)$ & $(57-87)$ & $(7.6-13.1)$ & $(0.09-1.5)$ & \\
\hline
\end{tabular}

PPV : Positive Predictive Value.

NPV : Negative Predictive Value.
+LR : Positive likelihood ratio.

-LR : Negative likelihood ratio. 


\section{Discussion}

The available information confirms that a large amount of full-length CTGF which were known to be present in platelets were shown to be released into plasma by platelet activation during or after blood collection and may interfere with determination of plasma CTGF levels [14], which is considered to reflect fibrosis in a variety of organs. We therefore focused our investigation on a novel subtraction method for accurately determining plasma CTGF levels [10].

To our knowledge, we demonstrated for the first time that plasma CTGF levels were elevated in children with PAH-CHD. Cyanotic PAH-CHD had significantly higher levels of plasma CTGF than acyanotic PAH-CHD, but plasma CTGF levels also were higher in acyanotic PAH-CHD compared with HCG. Plasma CTGF levels were not correlated with PASP, PADP, RVSP, RVDP, mPAP, Qp, Qs, $\mathrm{Qp} / \mathrm{Qs}, \mathrm{Rp}, \mathrm{Rs}$ or Rp/Rs, respectively, while there was a negative relation between plasma CTGF levels and oxygen saturation. Plasma CTGF levels were associated with NYHA classes in PAH-CHD. Furthermore, even though the addition of CTGF to BNP did not significantly increase AUC for diagnosis of PAH-CHD compared with BNP alone, it revealed a moderately better specificity, PPV and positive likelihood ratio than BNP alone.

Accumulating data demonstrate that CTGF expression was regulated by several stimulating factors, for example mechanical stretch, pressure overload, TGF- $\beta$, oxidative and angiotensin II [16] Thus, it is reasonable that plasma CTGF levels were markedly elevated due to abnormal hemodynamics in children with PAH-CHD. On the other hand, as an important induced factor for $\mathrm{PAH}$, hypoxia increased secretion of CTGF [17]. Our results indicate that the mean mixed venous oxygen saturation of the children with PAH-CHD was approximately $88.9 \%$, suggesting that tissue hypoxia was slightly present; cyanotic $\mathrm{PAH}-\mathrm{CHD}$ had significantly higher levels of plasma CTGF than acyanotic PAH-CHD, but also oxygen saturation was negatively correlated with plasma CTGF levels. We therefore speculate that higher plasma CTGF levels in cyanotic PAH-CHD children than in other group that we studied may be explained, at least in part by this mechanism.

Several studies have found that CTGF participated in the development of pulmonary vascular remodeling [8]. Conversely, plasmid-based shRNA against CTGF prevented pulmonary vascular remodeling in cigarette smoke-exposed rats [18]
These experimental observations suggest that CTGF expression promotes accumulation of extracellular matrix and proliferation of pulmonary arterial smooth muscle cell and eventually leads to vascular remodeling. In previous studies, CTGF has been involved in many disease states characterized by fibrosis and also has been proposed as a biomarker of fibroproliferative disease [19].

Currently, hemodynamic parameters are key indicators for assessing progression and diagnosis of PAH, but alternative parameters to monitor disease severity and diagnosis which are noninvasive, reliable and relatively quick are urgently needed in children with PAH-CHD. It has been widely accepted that plasma BNP levels as a biomarker for PAH correlated with hemodynamic parameters in PAH Giannakoulas et al., [20] while in the present study, the significant relations of elevated plasma CTGF levels with hemodynamic parameters (i.e., PASP, PADP, RVSP, RVDP, mPAP, Qp, Qs, Qp/Qs, Rp, Rs or Rp/Rs) have not been observed, indicating that BNP and CTGF may capture different aspects of PAH-CHD pathophysiology. Immunohistochemical stains of lungs from rat PAH model showed that CTGF was markedly expressed in pulmonary arterial smooth muscle cells [9]. Moreover, vascular remodeling closely associates with pulmonary arterial smooth muscle cells proliferation in PAH. Increased plasma levels of CTGF seem to mirror remodeling processes. Taken together, CTGF is unable to directly relate to and cannot be considered a indicator for the severity of PAH-CHD; thus, CTGF has no prognostic potential. Additionally, Kono et al., [11] demonstrated that plasma CTGF levels were higher in idiopathic pulmonary fibrosis patients and negatively correlated with 6-month change in force vital capacity. Elevated plasma CTGF levels in adult patients with asthma which negatively correlated with force vital capacity, forced expiratory volume in $1 \mathrm{~s}$, were considered to be a clinical biomarker of asthma [21].

BNP is secreted mainly from ventricle in response to volume load and pressure load. Increased plasma BNP levels were correlated with NYHA classes in PAH. We also confirmed an association of plasma CTGF levels with NYHA classes in our study population. Furthermore, although exogenous BNP inhibited the expression of CTGF Giannakoulas et al., [20] increased plasma CTGF levels correlated with BNP in our trial. These findings indicate that plasma CTGF levels may reflect, to some extent, cardiac pathologies, especially right heart dysfunction in PAH-CHD. Supporting this hypothesis, similar relations between plasma levels 
of CTGF and BNP have been observed in adult patients with heart failure [19]. Owing to pathobiology of PAH induced by multifactor, a single biomarker will not be precise for the diagnosis, prognosis and aspects of the underlying disease process for PAH. Thus, a combination of several biomarkers could be the optimal proposal to improve the diagnosis and prognosis. Recently, $(\mathrm{Ni}-$ ckel et al., 2008) demonstrated that the addition of growth differentiation factor-15 to NT-proBNP could improve prognostic value in idiopathic PAH. Notably, as shown in this trial, the combination of CTGF with BNP did not significantly increase AUC for diagnosing PAH-CHD compared with BNP alone in this study, whereas its specificity, PPV and positive likelihood ratio reached 93, 91 and $10.0 \%$, respectively. These findings clearly indicate that CTGF could be a promising diagnostic biomarker for PAH-CHD in children.

There were several limitations in our study. Firstly, this is a single-center study and sample size needs to be enlarged. Secondly, a study with a longer follow-up period should be executed to evaluate the relation between plasma CTGF levels and clinical hemodynamic parameters. Thirdly, there will be a topic of future studies to investigate the plasma CTGF levels in various conditions of PAH. Fourthly, more work is required to validate the supposition that CTGF is a novel diagnostic biomarker.

\section{Conclusion:}

Plasma CTGF levels could be a promising diagnostic biomarker for PAH-CHD in children.

\section{References}

1- SIMONNEAU G., GALIE N., RUBIN L.J., LANGLEBEN D., SEEGER W., DOMENIGHETTI G., GIBBS S., LEBREC D., SPEICH R., BEGHETTI M., RICH S. and FISHMAN A.: Clinical classification of pulmonary hypertension. J. Am. Coll. Cardiol., 43: 5S-12S, 2004.

2- BARST R.J., McGOON M., TORBICKI A., TORBICKI A., SITBON O., KROWKA M.J., OLSCHEWSKI H. and GAINE S.: Diagnosis and differential assessment of pulmonary arterial hypertension. J. Am. Coll. Cardiol., 43: 40S-47S, 2004.

3- GATZOULIS M.A., ALONSO-GONZALEZ R. and BEGHETTI M.: Pulmonary arterial hypertension in paediatric and adult patients with congenital heart disease. Eur. Respir. Rev., 18: 154-61, 2009.

4- MONTANI D., CHAUMAIS M.C., GUIGNABERT C., GUNTHER S., GIRERD B., JAIS X., ALGALARRONDO V., PRICE L.C., SAVALE L., SITBON O., SIMONNEAU G. and HUMBERT M.: Targeted therapies in pulmonary arterial hypertension. Pharmacol. Ther., 141: 172-91, 2014.
5- BIENERTOVA-VASKU J., NOVAK J. and VASKU A.: MicroRNAs in pulmonary arterial hypertension: Pathogenesis, diagnosis and treatment. J. Am. Soc. Hypertens, 9: 221-34, 2015.

6- BRADHAM D.M., IGARASHI A., POTTER R.L. and GROTENDORST G.R.: Connective tissue growth factor: a cysteine-rich mitogen secreted by human vascular endothelial cells is related to the SRC-induced immediate early gene product CEF-10. J. Cell. Biol., 114: 1285-94, 1991.

7- HISHIKAWA K., OEMAR B.S., TANNER F.C., NAKAKI T., LUSCHER T.F. and FUJII T.: Connective tissue growth factor induces apoptosis in human breast cancer cell line MCF-7. J. Biol. Chem., 274: 37461-6, 1999.

8- LEE Y.S., BYUN J., KIM J.A., LEE J.S., KIM K.L., SUH Y.L., KIM J.M., JANG H.S., LEE J.Y., SHIN I.S., SUH W., JEON E.S. and KIM D.K.: Monocrotaline-induced pulmonary hypertension correlates with upregulation of connective tissue growth factor expression in the lung. Exp. Mol. Med., 37: 27-35, 2005.

9- WANG R., XU Y.J., LIU X.S., ZENG D.X. and XIANG M.: CCN2 promotes cigarette smoke-induced proliferation of rat pulmonary artery smooth muscle cells through upregulating cyclin D1 expression. J. Cell Biochem., 113: 349-59, 2012.

10- BEHNES M., BRUECKMANN M., LANG S., WEISS C., AHMAD-NEJAD P., NEUMAIER M., BORGGREFE M. and HOFFMANN U.: Connective tissue growth factor (CTGF/CCN2): Diagnostic and prognostic value in acute heart failure. Clin. Res. Cardiol., 103: 107-16, 2014.

11- KONO M., NAKAMURA Y., SUDA T., KATO M., KAIDA Y., HASHIMOTO D., INUI N., HAMADA E., MIYAZAKI O., KURASHITA S., FUKAMACHI I., ENDO K., NG P.S., TAKEHARA K., NAKAMURA H., MAEKAWA M. and CHIDA K.: Plasma CCN2 (connective tissue growth factor; CTGF) is a potential biomarker in idiopathic pulmonary fibrosis (IPF). Clin. Chim. Acta, 412: 2211-5, 2011.

12- DZIADZIO M., USINGER W., LEASK A., ABRAHAM D., BLACK C.M., DENTON C. and STRATTON R.: Nterminal connective tissue growth factor is a marker of the fibrotic phenotype in scleroderma. QJM, 98: 485-92, 2005.

13- LOWE B.S., THERRIEN J., IONESCU-ITTU R., PILOTE L., MARTUCCI G. and MARELLI A.J.: Diagnosis of pulmonary hypertension in the congenital heart disease adult population impact on outcomes. J. Am. Coll. Cardiol., 58: 538-46, 2011.

14- CICHA I., GARLICHS C.D., DANIEL W.G. and GOPPELT-STRUEBE M.: Activated human platelets release connective tissue growth factor. Thromb. Haemost., 91: 755-60, 2004.

15- MIYAZAKI O., KURASHITA S., FUKAMACHI I., ENDO K., NG P.S. and TAKEHARA K.: Subtraction method for determination of $\mathrm{N}$-terminal connective tissue growth factor. Ann. Clin. Biochem., 47: 205-11, 2010.

16- BLOM I.E., GOLDSCHMEDING R. and LEASK A.: Gene regulation of connective tissue growth factor: New targets for antifibrotic therapy. Matrix Biol., 21: 473-82, 2002. 
17- HUANG X., ZOU L., YU X., CHEN M., GUO R., CAI H., YAO D., XU X., CHEN Y., DING C., CAI X. and WANG L.: Salidroside attenuates chronic hypoxia-induced pulmonary hypertension via adenosine A2a receptor related mitochondria-dependent apoptosis pathway. J. Mol. Cell Cardiol., 82: 153-66, 2015.

18- WANG R., XU Y.J., LIU X.S., ZENG D.X. and XIANG M.: Knockdown of connective tissue growth factor by plasmid-based short hairpin RNA prevented pulmonary vascular remodeling in cigarette smoke-exposed rats. Arch. Biochem. Biophys., 508: 93-100, 2011.

19- KOITABASHI N., ARAI M., NIWANO K., WATANABE A., ENDOH M., SUGUTA M., YOKOYAMA T., TADA H., TOYAMA T., ADACHI H., NAITO S., OSHIMA S., NISHIDA T., KUBOTA S., TAKIGAWA M. and KURABAYASHI M.: Plasma connective tissue growth factor is a novel potential biomarker of cardiac dysfunction in patients with chronic heart failure. Eur. J. Heart Fail., 10: 373-9, 2008.

20- GIANNAKOULAS G., MOURATOGLOU S.A., GATZOULIS M.A. and KARVOUNIS H.: Blood biomarkers and their potential role in pulmonary arterial hypertension associated with congenital heart disease. A systematic review. Int. J. Cardiol., 174: 618-23, 2014.

21- KATO M., FUJISAWA T., HASHIMOTO D., KONO M., ENOMOTO N., NAKAMURA Y., INUI N., HAMADA E., MIYAZAKI O., KURASHITA S., MAEKAWA M. and SUDA T.: Plasma connective tissue growth factor levels as potential biomarkers of airway obstruction in patients with asthma. Ann. Allergy Asthma. Immunol., 113: 295-300, 2014.

\section{دور عامل نهو النسيج الضام بالبلازما إزما

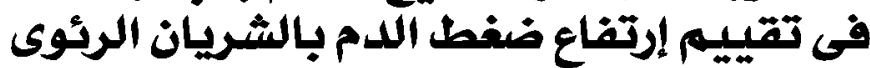

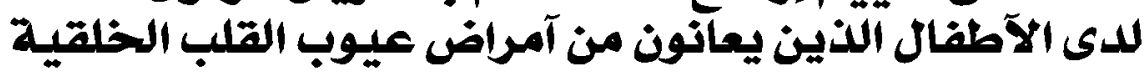

إن إرتفاع ضفط الدم بالثريان الرئوى من الآمراض الخطيرة التى تسبب إرتفاع عدد الوفيات نتيجة فشل عضلة القلب عن آداء الثقاء وظائفها،

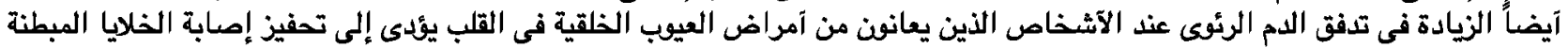

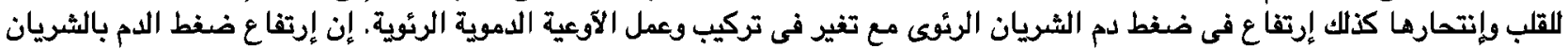

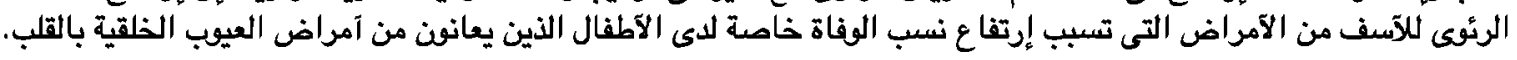

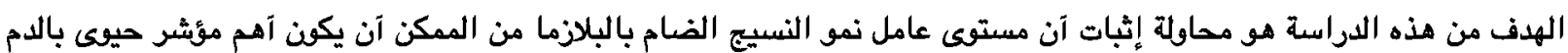

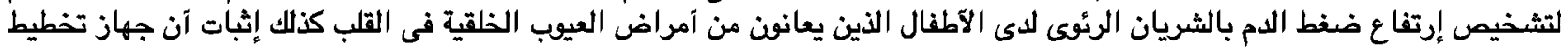

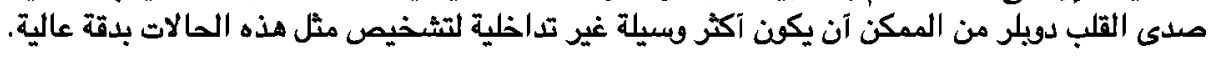

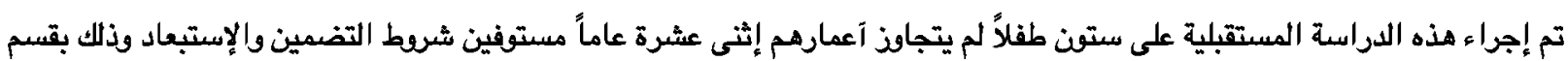

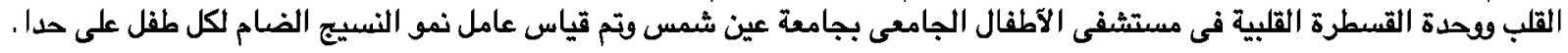
جميع الآطفال محل الدراسة قد خضعوا لآخذ تاريخ مفصل شاملاً العمر والسن والجنس والشكىى من آى آمراض مزمنة بجانب الفحص

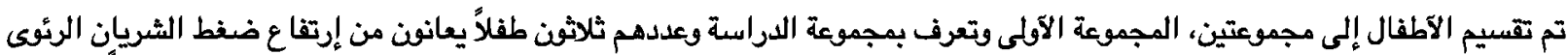

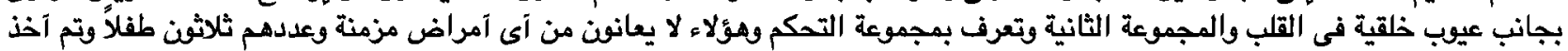

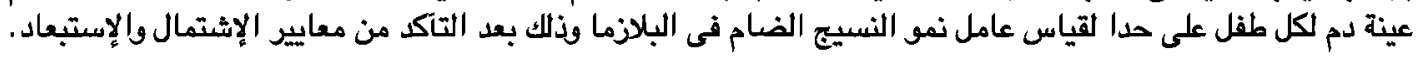

آيضاً تم عمل القسطرة القلبية لآطفال المجموعة الآولى لمعرفة معايير الدودة الدموية ومعرفة مدى تآثر عامل نمو النسيج الضام بالبلازما الهؤلاء الآطفال.

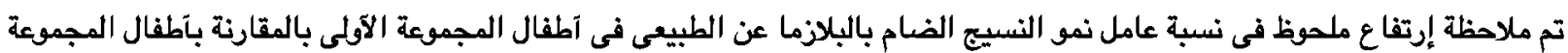
الثانية كذالك كان الإرتفاع ملحوظ فى بعض آمراض العيوب الخلقية اللقلب آكثر من الإرتفاع فى البعى البعض الآخر.

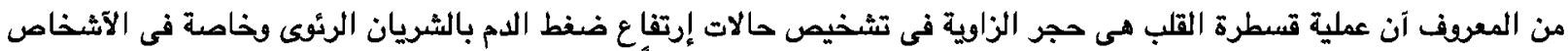

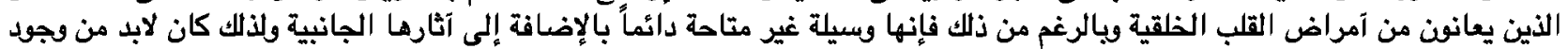

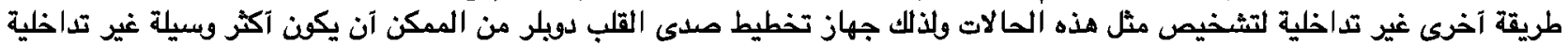
التثخيص مثل هذه الحالات بدقة عالية.

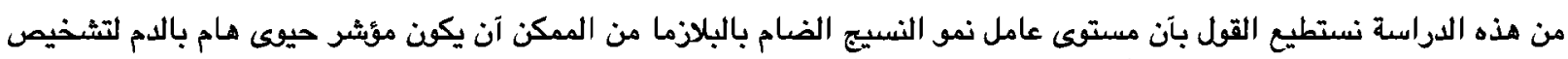

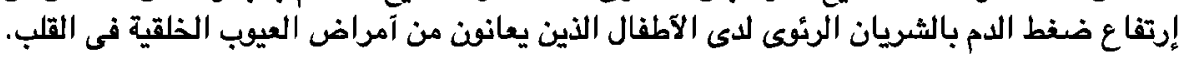

